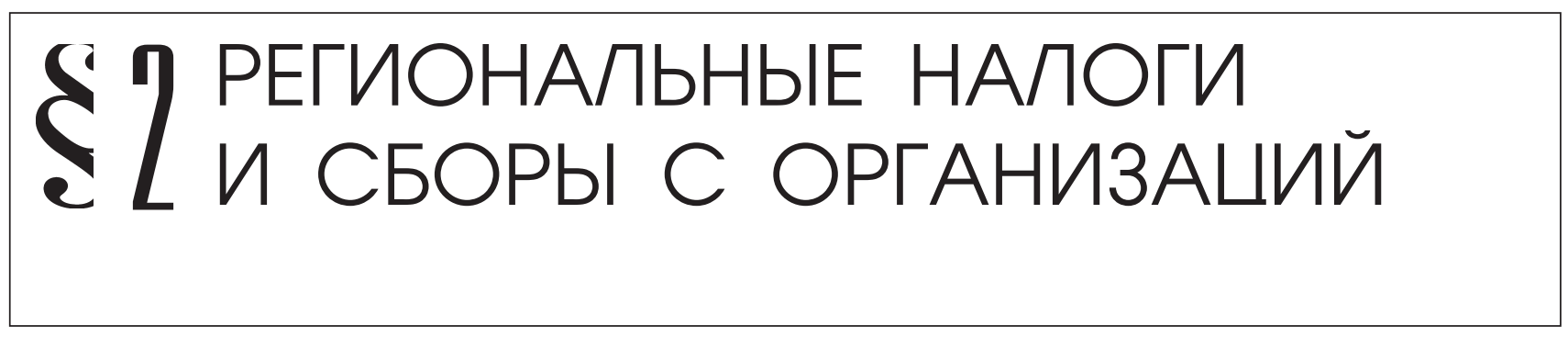

А.Г. Казьмин

\title{
НАЛОГООБЛОЖЕНИЕ ТРАНСПОРТНЫХ СРЕДСТВ НА ТЕРРИТОРИИ РОССИИ, ПРОБЛЕМЫ И ПУТИ СОВЕРШЕНСТВОВАНИЯ
}

Аннотация: Оценка поступления сумм транспортного налога в бюджетную систе-му $Р \Phi$, в условия кризисных тенденций позволит ответить на вопрос о поступлении финансовых ресурсов для обеспечения деятельности регионов. Объем и динамика строительства дорог в России. Анализ типов финансирования специиализированных фондов развития дорожной сети, методы и способы налогообложения транспортных средств. Результаты исследования статистических и аналитических данных на макро и микроуровне позволили сделать вывод о том, что существующие темпы строительства дорожной сети существенно тормозят экономическое развитие страны.

Ключевые слова: налогообложение, транспортный налог, налоговая база, автотранспорт, методы и способы взимания транспортного налога, налоговые ставки.

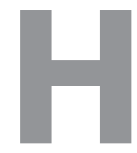

алоговая система РФ имеет три уровня: федеральный, региональный и местный, тем самым отражая федеративный характер российского государства. Наделение субъектов РФ определенными самостоятельными полномочиями в части их правового регулирования региональных налогов, позволяет отчасти обеспечить региональные бюджеты необходимыми денежными средствами.

Налоги остаются одним из важнейших инструментов осуществления экономической политики государства. При этом государство может использовать налоги через присуще им функции, и прежде всего, фискальную и стимулирующую, если в обществе создана атмосфера должного уважения к налогу, основанная на понимании, экономической необходимости существования налоговой системы ${ }^{1}$ В той связи предпочтительным становиться изучение истории становления и развития транспортного налогообложения на Руси.

С древнейших времен на Руси главными средствами сообщения служили водные пути, соединенные между собою волоками. Но мосты строились уже с глубокой древности, как это видно из «Русской Правды», установившей размер мостовой пошлины. Московские государи много заботились об

\footnotetext{
${ }^{1}$ Петухова, Н.Е. История налогообложения в России IX-XX вв./H.Е. Петухова - М.: Вузовский учебник, 2012. - C. 21
} 


\section{Налоги и налогообложение - №1(103) • 2013}

организации почты; но для улучшения самих дорог никаких мер не предпринималось; запрещалось только землевладельцам запахивать пролегающие через их земли дороги.

К упорядоченному строительству дорог правительство приступает только при Петре I, который наблюдение за догами в губерниях возложил на земских комиссаров, но после его кончины должность эта была упразднена. В конце царствования Петра I Камер-Коллегия предлагала большие дорог сооружать на счет казны, а меньшие разделить, по шведскому образцу, на участки, содержание которых возложить на крестьян; но в действительности внимание правительства привлекали только некоторые дороги (между Петербургом и Волховом, потом между обеими столицами).

С 1786 по 1796 г. существовала комиссия о дорогах в государстве, которой было поручено сочинение дорожной карты для всего государства и разделение дорог на статьи по степени их важности.

В 1816 г. дороги, по степени важности, разделены на 4 разряда, а для покрытия издержек по постройке дорог установлен особый сбор по 25 коп. с каждой ревизской души и по 5 \% с платимых купцами налогов (отменен в 1861 г.). В 1833 г. установлено новое, поныне сохранившееся разделение дорог на пять классов:

- дороги главных сообщений, или государственные;

- дороги больших сообщений;

- д дороги обыкновенных почтовых сообщений из губернии в губернию;

- дороги уездных почтовых и торговых сообщений;

- дороги сельские и полевые.

Дороги первого класса (шир. 60 саж.) и некоторые из дорог второго и третьего классов отнесены к ведомству центр. управления; предполагалось обратить их в шоссе на счет казны. В то же время для постройки и содержания на счет земских повинностей. Дороги 2, 3 и 4 классов (ширина 30 саж.) учреждены губернские строительные и дорожные комиссии и уездные дорожные комиссии. Одновременно с образованием министерства путей сообщения в 1865 г. дорожные комиссии упразднены и функции их по дорожной части переданы вновь открытым земским учреждениям, которым предоставлено было разделить дороги на две категории - губернские и уездные ${ }^{2}$.

Для содержания дорог земские учреждения и распорядительные комитеты располагают земскими повинностями, денежными и натуральными. Для отбывания натуральных дорожных повинностей дороги разделяются на участки, и к каждому участку приписывается часть окрестных селений.

В 1887 г. всеми земскими учреждениями израсходовано деньгами на дорожную часть 2717424 р., т. е. около 6 \% общей суммы земских расходов; в одних земствах расходы на дорожную часть составляли 10,6 \% (пермское), в других - лишь 1,6 \% (самарское). С развитием сети железных дорог дороги главных и больших сообщений, находящиеся в ведении минимальных путей сообщения, потеряли свое значение, вследствие чего правительство (с 1871 г.) стало передавать их в заведование земств (до 1917 г.) ${ }^{3}$.

После Октябрьской революции и Гражданской войны в молодой советской республике содержанию дорог не уделяется должного внимания, так как на повестке дня стояли более важные вопросы. Содержание дорог оставалось в ведении местных органов

2 Петухова, Н.Е. История налогообложения в России IX-XX вв./H.E. Петухова - М.: Вузовский учебник, 2012. - C. 52

3 Петухова, Н.Е. История налогообложения в России IX-XX вв./Н.Е. Петухова - М.: Вузовский учебник, 2011. - C. 189 
власти. Дальнейшее развитие транспортного налогообложения в нашей стране продолжилось с введения в 1942 году сбора с владельцев транспортных средств. Указ Президиума Верховного Совета СССР от 10 апреля 1942 г. «О местных налогах и сборах» определял все существенные элементы налогообложения ${ }^{4}$. Был установлен сбор с владельцев транспортных средств, к которым относились автомобили, мотоциклы, велосипеды, яхты, лодки, ялики, паромы, а также выездные и рабочие лошади, и некоторые другие животные, используемые в народном промысле.

В более поздний период порядок взимания налога с владельцев транспортных средств, регулируемый указами Президиума Верховного Совета СССР, дифференцировался на территории столиц союзных и автономных республик, краевых (областных) центров, дачных и курортных поселков, прочих населенных пунктов в зависимости от административной значимости населенного пункта.

Начиная с 1991 г. в соответствии с Законом РСФСР от 18 октября 1991 г. № 17591 «О дорожных фондах в РСФСР» и Законом РФ «Об основах налоговой системы РФ» от 27 декабря 1991 г. № 2118-1 к федеральным и территориальным налогам были отнесены налоги, служащие источниками образования дорожных фондов. Налоги, зачисляемые в дорожные фонды, носили целевой характер и служили источниками финансирования затрат, связанных с содержанием, ремонтом, реконструкцией и строительством автомобильных дорог общего пользования общегосударственного и местного значения.

Данный закон предусматривал налог на пользователей автомобильных дорог, который уплачивали предприятия, объединения, учреж-

${ }^{4}$ Собрание действующего законодательства СССР. T. 14. С. 433. дения и организации (кроме заготовительных, торгующих и снабженческо - сбытовых организаций) независимо от форм собственности и ведомственной принадлежности в размере 0,4 \% объема производства продукции, выполняемых работ и предоставляемых услуг. Заготовительные, торгующие (в том числе организации оптовой торговли) и снабженческо сбытовые организации уплачивали данный налог в размере $0,03 \%$ годового оборота. На тот момент, дорожный фонд РФ состоял из федерального и территориального дорожных фондов, создаваемых в соответствии с законами субъектов РФ. До 1 января 2003 г. основными источниками образования целевых средств территориальных дорожных фондов были налог на пользователей автомобильных дорог и налог с владельцев транспортных средств. Транспортный же налог был отнесен к региональным налогам и сборам (п.п. «ж» п. 1 ст. 20 Закона Российской Федерации от 27.12.91 г. № 2118-І «Об основах налоговой системы в Российской Федерации»). Это означало, что данный налог подлежало уплачивать только на территории того субъекта Российской Федерации, где принятым в соответствии с Кодексом соответствующим законом субъекта Российской Федерации налог введен в действие.

Плательщиками налога на пользователей автомобильных дорог являлись юридические лица, индивидуальные предприниматели, предприятия с иностранными инвестициями, международные объединения и организации, осуществляющие предпринимательскую деятельность. Объектом налогообложения служила выручка от реализации товаров (работ, услуг) либо сумма разницы между продажной и покупной ценами товаров, реализованных в результате заготовительной, снабженческо-сбытовой и торговой деятельности. Ставка налога устанавливалась в размере $1 \%$. 


\section{Налоги и налогообложение - №1(103) • 2013}

В РФ транспортный налог был введен Указом Президента РФ «О некоторых изменениях в налогообложении и во взаимоотношениях бюджетов различных уровней» от 22 декабря 1993 г. № 2270. Налог взимался только с предприятий и организаций, за исключением бюджетных организаций, и объектом налогообложения были не транспортные средства, а фонд оплаты труда по ставке 1\%. Средства от налога направлялись в бюджеты субъектов РФ для финансовой поддержки и развития пассажирского автомобильного транспорта, городского электротранспорта, пригородного пассажирского железнодорожного транспорта. Указом Президента РФ в 1997 г. «О признании утратившими силу некоторых Указов Президента РФ» от 15 ноября 1997 г. № 1233 транспортный налог был упразднен.

В рамках реформирования налоговой системы РФ первоначально планировалось с 1 января 2003 г. отменить Закон о дорожных фондах в России. Однако, Федеральным законом «О внесении изменений и дополнений в часть вторую Налогового кодекса РФ» и некоторые другие акты законодательства РФ от 24 июля 2002 г. № 110-ФЗ. Были внесены существенные изменения в налоговое законодательство, связанные с формированием системы финансирования затрат по содержанию, ремонту, реконструкции и строительству автомобильных дорог общего пользования, а именно:

- исключена ст. 5 Федерального закона № 118-Ф3, предусматривавшая отмену Закона о дорожных фондах;

- в Закон о дорожных фондах в РФ были внесены изменения, касающиеся уточнения формирования источников образования территориальных дорожных фондов;

- часть вторая Налогового кодекса РФ была дополнена новой главой 28 «Транспортный налог».
В отличие от транспортного налога, введенного Указом Президента РФ № 2270, транспортный налог, предусмотренный главой 28 Налогового кодекса России, является:

- $\quad$ региональным - средства от него поступают в бюджет субъектов Федерации;

- $\quad$ косвенным - так как включается в расходы организации, тем самым увеличивает себестоимость продукции, влияет на увеличение налоговой нагрузки и уплачивается конечным потребителем (хотя с точки зрения современного НК РФ он относится к прямым);

- имущественным - взимается с имущества. С вступлением в силу с 1 января 2003 г. гл. 28 «Транспортный налог» НК РФ на территории России был отменен налог с владельцев транспортных средств и налог на пользователей автомобильных дорог. Кроме того, водно-воздушные транспортные средства исключены из объектов налогообложения, перечисленных в Законе РФ «О налогах на имущество физических лиц» от 9 декабря 1991 г. № $2003-1$.

С 1 января 2003 г. по 31 декабря 2004 г. транспортный налог наряду с другими налогами был источником образования территориальных дорожных фондов, т. е. являлся маркированным. С 1 января 2005 г., после отмены Закона РФ «О дорожных фондах РФ» от 18 октября 1991 г. №1759 - 1, транспортный налог перешел в категорию общих налогов, формирующих доходную часть региональных бюджетов.

С введением транспортного налога из числа налогов, взимаемых на территории РФ, были исключены:

- налог на пользователей автодорог;

- налог с владельцев транспортных средств;

- $\quad$ акцизы с продажи легковых автомобилей в личное пользование граждан;

- $\quad$ налог на водно-воздушные транспортные средства, ранее уплачиваемый физиче- 
скими лицами в соответствии с Законом РФ от 19.12.91 № 2003-1 «О налогах на имущество физических лиц» (ст. 3 Закона № 110-Ф3). Во многих субъектах РФ приняты соответствующие законы о транспортном налоге.

Элементы налогообложения в отношении транспортного налога установлены гл. $28 \mathrm{HK}$ РФ «Транспортный налог». Стало быть, принимая региональный закон о транспортном налоге на подведомственной ему территории, субъект РФ должен руководствоваться поло- жившаяся судебная практика свидетельствует о применении весьма сложной, противоречивой и несовершенной модели транспортного налога. Отсутствуют четкие критерии определения объектов налогообложения, возникают сложности с применением налоговых льгот.

Сегодня одним из направлений совершенствования налогового федерализма должно стать создание такой правовой модели транспортного налога, которая одновременно сочетала бы интересы Федерации, субъектов РФ и налогоплательщиков.

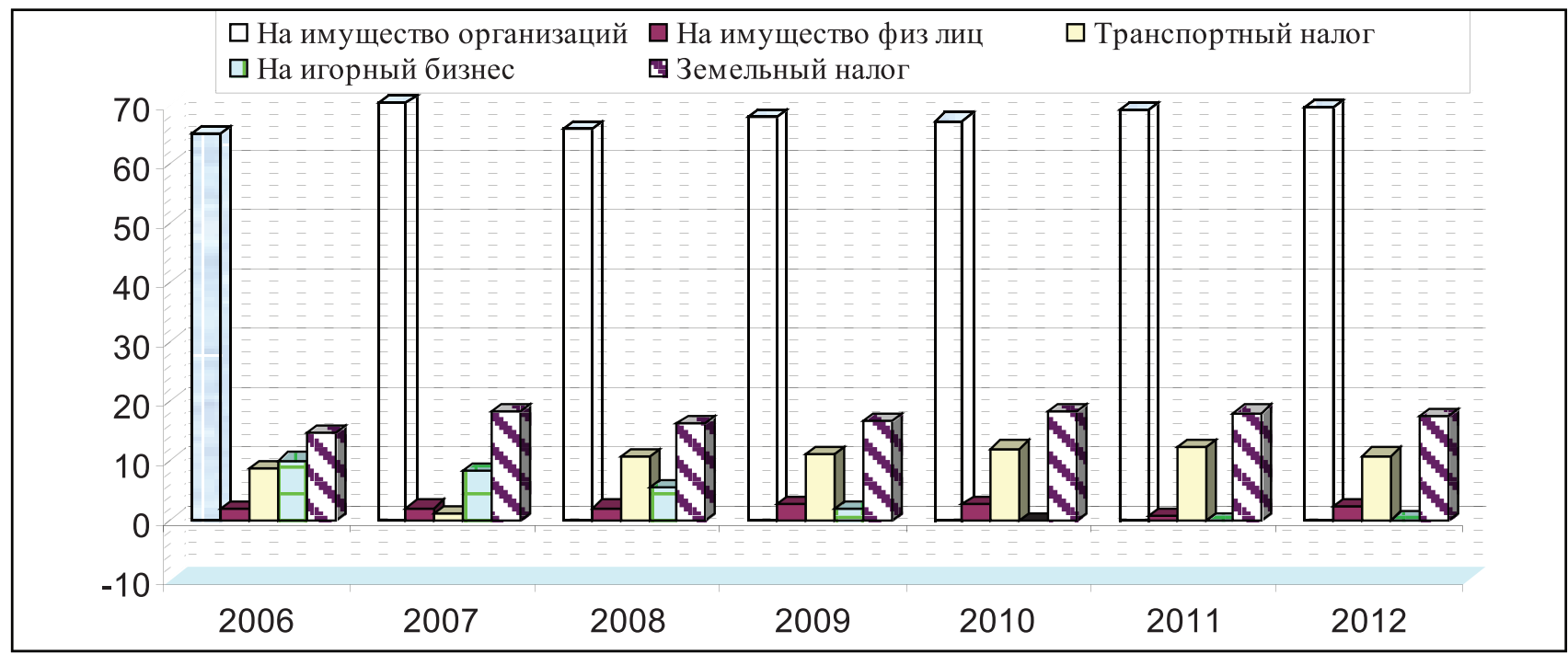

Рисунок 1 - Динамика поступления налогов в региональный бюджет субъектов РФ в \%

жениями гл.28 НК РФ, которой определены налогоплательщики, объект налогообложения, налоговая база, налоговый период, налоговые ставки, порядок исчисления налога. При этом, устанавливая транспортный налог, органы власти соответствующего субъекта РФ не вправе расширительно толковать нормы, закрепленные гл.28 НК РФ в отношении иных элементов налогообложения.

В настоящее время его роль в пополнении доходной части региональных бюджетов невелика и не превышает $10 \%$ от общей величины дохода субъекта РФ (Рис. 1). В тоже время сло-
Постоянные изменения, вносимые в Налоговый Кодекс РФ, осуществляются бессистемно, хаотично, без достаточной научной обоснованности, что порождает бесконечный процесс «совершенствования налогового законодательства».

Законность транспортного налога включает в себя два уровня: федеральный и региональный. Правовая модель транспортного налога органично сочетает федеральный компонент в виде установления транспортного налога и региональный в виде его введения. Федеральным законодательством 


\section{Налоги и налогообложение - №1(103) 2013}

предусмотрена рамочная компетенция законодательных органов власти субъектов РФ при введении транспортного налога. Транспортный налог в его действующей правовой модели выполняет в основном фискальную функцию5.
С 2003 по 2010 год ставки транспортного налога могли быть увеличены или уменьшены но не более чем в 5 раз. С 2011 года эти налоговые ставки могут быть увеличены законами субъектов Российской Федерации, но не более чем в 10 раз.

Таблица 1 - Ставки транспортного налога установленные НК РФ

\begin{tabular}{|c|c|c|c|c|c|c|c|c|c|c|}
\hline $\begin{array}{c}\text { Автомобили легко- } \\
\text { вые с мощностью } \\
\text { двигателя } \\
\text { (руб. с каждой лоша- } \\
\text { диной силы): }\end{array}$ & 2004 & 2005 & 2006 & 2007 & 2008 & 2009 & 2010 & 2011 & 2012 & 2013 \\
\hline 1 & 2 & 3 & 4 & 5 & 6 & 7 & 8 & 9 & 10 & 11 \\
\hline $\begin{array}{l}\text { свыше } 70 \text { л.с. до } 100 \text { л.с. } \\
\text { (свыше 51,49 кВт до } \\
73,55 \text { кВт) } \\
\text { включительно }\end{array}$ & 5 & 5 & 5 & 5 & 5 & 5 & 5 & 2,5 & 2,5 & 2,5 \\
\hline $\begin{array}{l}\text { свыше } 100 \text { л.с. до } 150 \text { л.с. } \\
\text { (свыше } 73,55 \text { кВт до } \\
\text { 110,33 кВт) } \\
\text { включительно }\end{array}$ & 7 & 7 & 7 & 7 & 7 & 7 & 7 & 3,5 & 3,5 & 3,5 \\
\hline $\begin{array}{l}\text { свыше } 150 \text { л.с. } \\
\text { до } 200 \text { л.с. (свыше } \\
\text { 110,33 кВт до 147,1 кВт) } \\
\text { включительно }\end{array}$ & 10 & 10 & 10 & 10 & 10 & 10 & 10 & 5 & 5 & 5 \\
\hline $\begin{array}{l}\text { свыше } 200 \text { л.с. до } 250 \text { л.с. } \\
\text { (свыше } 147,1 \text { кВт кВт } \\
\text { до 183,9 кВт) } \\
\text { включительно }\end{array}$ & 15 & 15 & 15 & 15 & 15 & 15 & 15 & 7,5 & 7,5 & 7,5 \\
\hline $\begin{array}{l}\text { свыше } 250 \text { л.с. } \\
\text { (свыше 183,9 кВт) }\end{array}$ & 30 & 30 & 30 & 30 & 30 & 30 & 30 & 15 & 15 & 15 \\
\hline
\end{tabular}

${ }^{5}$ Берестовой $A$. A. Правовое регулирование транспортного налога : дис. ... канд. юрид. наук : 12.00.14 / А. А. Берестовой; Ростов-на-Дону, Рост. гос. эконом. ун-т ; науч. рук. А. Н. Позднышов. - Ростов-на-Дону, 2012.- C. 47 
Региональные налоги и сборы с организаций

Анализ мировой практики позволяет выделить несколько основных типологически различных механизмов платы за пользование дорогами. Возникновение и развитие каждого из них, так или иначе, связано с ролью, которую дороги играли в государстве и обществе, наличием достаточно массовой категории пользователей сети, и, наконец, явно или неясно принятым «общественным договором» между пользователями сети и органами государственной власти. В настоящее время выделяют ряд основных типов, к которым с теми или иными вариациями сводятся все, известные в истории и практике дорожного хозяйства, механизмы платы за пользование дорогами (табл. 2).

Таблица 2 - Механизмы плать за пользование дорогами

\begin{tabular}{|c|c|c|}
\hline Тип & Способ взимания и основные цели & Основные недостатки \\
\hline 1 & 2 & 3 \\
\hline $\mathbf{A}_{1}$ & $\begin{array}{l}\text { Взимались в виде дорожных повинностей или подати } \\
\text { для населения и хозяйствующих субъектов. Исполь- } \\
\text { зуются косвенные формы уплаты подати для разви- } \\
\text { тия дорожного хозяйства. }\end{array}$ & $\begin{array}{l}\text { Носили не регулярный и не } \\
\text { равномерный характер. Не име- } \\
\text { ли четкой организации и целей } \\
\text { строительства. }\end{array}$ \\
\hline $\mathbf{A}_{2}$ & $\begin{array}{l}\text { Собранные сумы направлялись на финансирование } \\
\text { дорожного хозяйства из общих доходов центральной } \\
\text { казны. С целью формирования базовой сети дорог, а } \\
\text { также в связи с реализацией крупных дорожных про- } \\
\text { ектов, направленных на закрепление политического } \\
\text { и фискального контроля центральной власти над про- } \\
\text { винциями и решение военно-стратегических задач. }\end{array}$ & $\begin{array}{l}\text { В основном на нужды развития } \\
\text { дорожной сети привлекались } \\
\text { средства государственной каз- } \\
\text { ны, что не всегда способство- } \\
\text { вало развитию дорожной сети. } \\
\text { Темпы развития дорожной сети } \\
\text { не соответствовали потребно- } \\
\text { стям экономики. }\end{array}$ \\
\hline $\mathrm{B}_{1}$ & $\begin{array}{l}\text { Взимались в виде дорожных пошлин за транзит и } \\
\text { перевозку грузов. Пошлины устанавливаются на } \\
\text { проезд отдельных участков дорог, мостов, тунне- } \\
\text { лей и других искусственных сооружений. Основная } \\
\text { цель решение задач организации дорожного движе- } \\
\text { ния и ни коим образом, не связано с рыночным ре- } \\
\text { формированием или коммерциализацией дорожно- } \\
\text { го хозяйства. }\end{array}$ & $\begin{array}{l}\text { Зачастую отдельные террито- } \\
\text { рии устанавливали довольно } \\
\text { завышенные размеры дорож- } \\
\text { ных пошлин, за пользование } \\
\text { теми или иными объектами до- } \\
\text { рожной инфраструктуры. }\end{array}$ \\
\hline $\mathbf{B}_{2}$ & $\begin{array}{l}\text { Используются целевые пользовательские налоги, } \\
\text { связанные с фактом владения автомобилем. Пред- } \\
\text { ставляют собой прямые формы платежей за право } \\
\text { доступа к дорожной сети. Взимаемые налоги не за- } \\
\text { висят от фактического пробега автомобиля, то есть } \\
\text { представляют собой условно-постоянную часть та- } \\
\text { рифа за пользования дорогами. }\end{array}$ & $\begin{array}{l}\text { Фиксированные размер платы } \\
\text { не учитывающий фактический } \\
\text { износ дорожной сети и нагруз- } \\
\text { ку на неё. Этот налог обеспе- } \\
\text { чивает до } 25 \% \text { консолидиро- } \\
\text { ванных расходов на дорожное } \\
\text { хозяйство. }\end{array}$ \\
\hline
\end{tabular}




\begin{tabular}{|c|l|l|}
\hline $\mathbf{B}_{3}$ & $\begin{array}{l}\text { Используются целевые пользовательские налоги или } \\
\text { сборы, прямо связанные с фактическим пробегом }\end{array}$ & Для наиболее полной реализа- \\
& транспортных средств, уровнем разрушающих воз- & ется оснащение транспортных \\
& действий на дорожную сеть и искусственные соору- & средств системами спутнико- \\
жения, объёмы выполненных работ по реконструкции & вого мониторинга движения \\
& и развитию транспортной инфраструктуры. Данный \\
механизм позволит обеспечить порядка 70\% консо- & автомобилей, типа GPS. \\
& лидированных расходов на дорожное хозяйство. & \\
\hline
\end{tabular}

Все эти механизмы представляют собой: некоторую форму платы за полезные внешние эффекты дорожной сети, то есть выгоды, которые власть, население и экономика региона или страны в целом получают по факту наличия дорог;

- некоторую форму платы за непосредственное пользование дорогой, взимаемой с пользователя - собственника транспортного средства.

- При типе $\mathrm{B}_{1}$ движение транспорта по дорогам организуется таким образом, что бы рассредоточить транзитные потки между имеющимися магистралями. Единственным способом решения этой задачи является введение платного доступа на самые лучшие дороги. Сюда выводится межрегиональный и международный грузовой транзит, а также пассажирские и туристические маршруты. К наиболее важным элементам данной схемы относят:

- применение стандартного механизма целевых дорожных налогов и дорожных фондов;

- плату за проезд собирают исключительно на дорогах высших технических категорий («хайвэях», «автобанах»);

- в европейских странах с развитыми законодательными нормами защиты прав потребителей величина ставок проездной платы составляет порядка $0,01-0,1$ евро/км;

- $\quad$ проездная плата позволяет содержать структуры организации дорожного движения (расширение проезжей части в местах нахождения пропускных пунктов, приобретение и эксплуатация специального), покрытия дополнительных затрат на содержание дороги по повышенным стандартам, а также на строительство и реконструкцию.

Появление механизмов типа $\mathrm{B}_{2}$ и $\mathrm{B}_{3}$, которые можно считать современными и базовыми для нормальной системы финансирования дорожного хозяйства, связано с развитием массовой автомобилизации населения, рубеж которой определяется тремя фундаментальными обстоятельствами.

Во-первых, автомобиль немедленно после своего появления предоставил его владельцу целый ряд преимуществ, включая большую автономность и скорость, и как следствие, - принципиально большую дистанцию преодолеваемого пути. Эти обстоятельства, предопределили принципиально новые стандарты расселения и трудовой маятниковой миграции. Массовая автомобилизация населения на два порядка (с единиц до сотен автомобилей на 1000 жителей) увеличила число регулярных пользователей дорожной сети. В этих связи становится возможным переложить бремя финансирования дорожной сети на еe регулярных пользователей, уйдя тем самым от архаичных дорожных повинностей, а также значительно сократив использование общих доходов бюджета. 
Во-вторых, соответствующее увеличение интенсивности дорожного движения делает невозможным преодоление множества трудностей и противоречий, возникающих при прямом сборе проездной платы на отдельных участках дорог, да еще принадлежащих разным собственникам. Эти трудности и противоречия связаны с тем, что при такой системе сбора (всегда предполагающей наличие шлагбаумов или турникетов) нарушаются равные права доступа к сети, а также снижается удобство пользования сетью дорог.

В-третьих, автомобиль потребляет моторное топливо, то есть энергетический ресурс, который заведомо не производится в домохозяйствах, и, следовательно, годится в качестве базы исчисления пользовательских дорожных налогов и сборов. Поэтому в рамках данного механизма:

- устанавливается система целевых дорожных налогов, сборов и платежей и разрабатывается номенклатура и ставки дорожных налогов;

- данные налоги позиционируются как форма платы за пользование дорогами и, соответственно, выделены структурно и функционально из общей массы других налогов поступающих в бюджетную систему;

- они используются в качестве основного макроэкономического регулятора спроса-предложения на пропускную способность дорожной сети;

- суммы собранных налогов распределяются между дорожными фондами имеющих иерархическую структуру в рамках трехуровневой бюджетной системы и аккумулируются в системе дорожных фондов;

- из дорожных фондов осуществляется финансирование соответствующих программ по эксплуатации, ремонту и строительству дорог;

- формируются механизмы учета и контроля за расходованием средств дорожных фондов, и общественного мнения по поводу направлений развития и совершенствования дорожной сети.

В зависимости от целей, которые ставит перед собой государство, применяют тот или иной тип дорожной политики и как следствие подстраивают под него механизмы финансирования.

В соответствии с федеральным законом № 110-Ф3 с 1 января 2003 года, отменяется налог пользователей автомобильных дорог и налог с владельцев автотранспортных средств и главой 28 Налогового кодекса РФ был вводится новый налог - транспортный, его плательщиками являются как юридические, так и физические лица. До того момента транспортный налог является основным источником финансирования дорожной отрасли, и от своевременности его поступления напрямую зависят сроки и качество исполнения строительных программ.

В настоящее время транспортный налог является одним из основных налогов субъектов Российской Федерации и занимает центральное место в системе имущественного налогообложения России. Принцип взимания транспортного налога похож на налог с владельцев автотранспортных средств. В соответствии со ст. 357 НК РФ, налогоплательщиками транспортного налога признаются лица, на которых в соответствии с законодательством РФ зарегистрированы транспортные средства, признаваемые объектом налогообложения в соответствии со статьей $358 \mathrm{HK}$ РФ. Порядок определения налоговой базы, устанавливаемой ст. 359 НК РФ, аналогичен по схеме порядку определения налоговой базы по налогу с владельцев транспортных средств, который взимался ранее 6 .

\footnotetext{
${ }^{6}$ Налоговый кодекс Российской Федерации часть первая от 31 июля 1998 г. № 146-Ф3 и часть вторая от 5 августа 2000 г. № 117-Ф3 (с изм. и доп. от 09.09.2012г.)
} 


\section{Налоги и налогообложение - №1(103)•2013}

В таблице 3 приведены суммы, поступившие от уплаты транспортного налога. В настоящее время наблюдается рост поступлений от данного налога.

Таблица 3 - Сумма транспортного налога, уплаченная организациями по России, в млн. руб.

\begin{tabular}{|l|c|c|c|c|c|c|}
\hline \multirow{2}{*}{\multicolumn{1}{|c|}{ Показатели }} & \multicolumn{7}{c|}{ Годы } \\
\cline { 2 - 7 } & $\mathbf{2 0 0 6}$ & $\mathbf{2 0 0 7}$ & $\mathbf{2 0 0 8}$ & $\mathbf{2 0 0 9}$ & $\mathbf{2 0 1 0}$ & $\mathbf{2 0 1 1}$ \\
\hline \multicolumn{1}{|c|}{1} & 2 & 3 & 4 & 5 & 6 & 7 \\
\hline $\begin{array}{l}\text { Сумма налога, подлежащая } \\
\text { уплате в бюджет }\end{array}$ & 13459,9 & 15342,9 & 17533,4 & 20053,5 & 21563,2 & 21712,9 \\
\hline $\begin{array}{l}\text { в том числе } \\
\text { по наземным транспортным } \\
\text { средствам }\end{array}$ & 12881,7 & 14734,7 & 16708,3 & 19064,3 & 20585,0 & 20756,1 \\
\hline $\begin{array}{l}\text { по водным транспортным } \\
\text { средствам }\end{array}$ & 413,0 & 452,0 & 493,1 & 561,5 & 624,1 & 631,5 \\
\hline $\begin{array}{l}\text { по воздушным транспортным } \\
\text { средствам }\end{array}$ & 165,2 & 156,2 & 332,0 & 427,6 & 354,1 & 325,3 \\
\hline
\end{tabular}

Рост поступлений наблюдается с 2006 года, и к 2011 он составил 21713 млн. руб. Наибольший удельный рост показывают отчисления с воздушных транспортных средств, в 2,7 раза, с наземных 1,5 раза, а наименьший с водных транспортных средств всего 1,4 раза.

Таблица 4 - Сумма транспортного налога уплаченная физ. лицами по России, в млн. руб.

\begin{tabular}{|l|c|c|c|c|c|c|}
\hline \multirow{2}{*}{\multicolumn{1}{|c|}{ Показатели }} & \multicolumn{7}{c|}{ Годы } \\
\cline { 2 - 7 } & $\mathbf{2 0 0 6}$ & $\mathbf{2 0 0 7}$ & $\mathbf{2 0 0 8}$ & $\mathbf{2 0 0 9}$ & $\mathbf{2 0 1 0}$ & $\mathbf{2 0 1 1}$ \\
\hline \multicolumn{1}{|c|}{1} & 2 & 3 & 4 & 5 & 6 & 7 \\
\hline $\begin{array}{l}\text { Сумма налога, подлежащая } \\
\text { уплате в бюджет }\end{array}$ & 30053,4 & 39050,1 & 48382,5 & 64769,7 & 73922,7 & 83684,8 \\
\hline $\begin{array}{l}\text { в том числе } \\
\text { по наземным транспортным } \\
\text { средствам }\end{array}$ & 29806,9 & 38737,1 & 47908,4 & 64204,2 & 73227,7 & 82920,1 \\
\hline $\begin{array}{l}\text { по водным транспортным } \\
\text { средствам }\end{array}$ & 245,4 & 310,3 & 456,9 & 543,3 & 665,4 & 731,9 \\
\hline $\begin{array}{l}\text { по воздушным транспортным } \\
\text { средствам }\end{array}$ & 1,0 & 2,8 & 17,3 & 22,2 & 29,6 & 32,8 \\
\hline
\end{tabular}


Рост поступлений наблюдается с 2006 года, и к 2011 он составил 83684,8 млн. руб. Наибольший удельный рост показывают отчисления с воздушных транспортных средств, в 33 раза, с наземных 2,1 раза, a с водных транспортных средств всего 3 раза.

При установлении транспортного налога субъект Российской Федерации вправе предусмотреть налоговые льготы и основания для их использования налогоплательщиком. Таким образом, в главе 28 НК РФ приведен исчерпывающе перечень транспортных средств, облагаемых транспортным налогом. В связи с разнородностью объектов налогообложения ст. 359 НК РФ предусматривается различный порядок определения налоговой базы в зависимости от мощности двигателя в транспортных средствах, валовой вместимости в регистровых тоннах или количества единиц транспортных средств и различные налоговые ставки.

В отличие от предыдущего периода времени, современный транспортный налог относится к так называемым поимущественным налогам. Его объектом являются транспортные средства, зарегистрированные за гражданами и организациями. При этом наблюдается постоянный рост зарегистрированных транспортных средств, что сказывается на росте доходной части региональных бюджетов (таблица 5 и 6) 7 .

Таблииа 5 - Количество зарегистрированных в базе налогового органа транспортных средств у юридических лич, единич

\begin{tabular}{|l|c|c|c|c|c|c|}
\hline \multirow{2}{*}{\multicolumn{1}{|c|}{ Показатели }} & \multicolumn{5}{|c|}{ Годы } \\
\cline { 2 - 8 } & $\mathbf{2 0 0 6}$ & $\mathbf{2 0 0 7}$ & $\mathbf{2 0 0 8}$ & $\mathbf{2 0 0 9}$ & $\mathbf{2 0 1 0}$ & $\mathbf{2 0 1 1}$ \\
\hline \multicolumn{1}{|c|}{1} & 2 & 3 & 4 & 5 & 6 & 7 \\
\hline $\begin{array}{l}\text { Всего транспортных } \\
\text { средств, из них }\end{array}$ & 4237562 & 4419410 & 4529154 & 4001023 & 4457625 & 4448966 \\
\hline $\begin{array}{l}\text { наземных транспортных } \\
\text { средств }\end{array}$ & 4200304 & 4379797 & 4488260 & 3963564 & 4411424 & 4402161 \\
\hline $\begin{array}{l}\text { водных транспортных } \\
\text { средств }\end{array}$ & 35151 & 37793 & 39074 & 35809 & 44246 & 44778 \\
\hline $\begin{array}{l}\text { воздушных транспортных } \\
\text { средств }\end{array}$ & 2107 & 1820 & 1820 & 1650 & 1955 & 2027 \\
\hline
\end{tabular}

7 Данные по формам статистической налоговой отчетности// www.nalog.ru: сервер Федеральной Налоговой Службы России. URL: http://www.nalog.ru/nal_statistik/ forms_stat (дата обращения 10.01. 2013) 


\section{Налоги и налогообложение - №1(103) • 2013}

За прошедшие 6 лет количество зарегистрированных транспортных средств у юридических лиц увеличилось на 211404 единицы. При этом число воздушных транспортных средств сократилось на 80 единиц. В период с 2007 по 2009 число зарегистрированных воздушных судов сократилось на 170 единиц. Хотя в последние годы наметилась тенденция к их увеличению. более двух полос движения: этого более чем достаточно при количестве транспортных средств, измеряемых несколькими единицами на 1000 жителей. Проблема пропускной способности дорог возникает сразу же, как только число активных пользователей дорожной сети начинает определяться количеством автотранспорта в размере нескольких сотен на 1000 жителей. Вопрос о регулиро-

Таблица 6 - Количество зарегистрированных в базе налогового органа транспортных средств у физических лии, единиц

\begin{tabular}{|l|c|c|c|c|c|c|}
\hline \multirow{2}{*}{\multicolumn{1}{|c|}{ Показатели }} & \multicolumn{7}{c|}{ Годы } \\
\cline { 2 - 7 } & $\mathbf{2 0 0 6}$ & $\mathbf{2 0 0 7}$ & $\mathbf{2 0 0 8}$ & $\mathbf{2 0 0 9}$ & $\mathbf{2 0 1 0}$ & $\mathbf{2 0 1 1}$ \\
\hline 1 & 2 & 3 & 4 & 5 & 6 & 7 \\
\hline $\begin{array}{l}\text { Всего транспортных } \\
\text { средств, из них }\end{array}$ & 31856546 & 33376658 & 35948914 & 34981039 & 38937265 & 42928433 \\
\hline $\begin{array}{l}\text { наземных транспортных } \\
\text { средств }\end{array}$ & 31570899 & 33063017 & 35562607 & 34564038 & 38457461 & 42384625 \\
\hline $\begin{array}{l}\text { водных транспортных } \\
\text { средств }\end{array}$ & 285578 & 313438 & 385659 & 416114 & 478545 & 541810 \\
\hline $\begin{array}{l}\text { воздушных транспортных } \\
\text { средств }\end{array}$ & 69 & 203 & 648 & 887 & 1259 & 1998 \\
\hline
\end{tabular}

У физических лиц мы наблюдаем значительный рост зарегистрированных транспортных средств с 2006 года на 11071877 единиц. Причем за 2012 год физическими лицами было приобретено ещё 2,5 миллионов автомобилей. Но наибольший рост увеличения числа зарегистрированных транспортных средств мы можем наблюдать среди воздушного транспорта. За рассматриваемый период их число возросло в 29 раз.

В этой ситуации по мере роста числа транспортных средств пропускная способность дорог становится чрезвычайно низкой. Даже самые лучшие дороги, построенные до периода 80-х годов XX века, имели не вании спроса-предложения на пропускную способность дорожной сети обсуждается в научной литературе европейских стран с конца 1960-ых годов.

Когда уровень автомобилизации США перешел рубеж 350 автомобилей на 1000 жителей, а западноевропейских стран - 180 автомобилей на 1000 жителей, была осознана ограниченность возможностей административных и инженерных методов регулирования спроса на пропускную способность дорог как такового. (в начале 2000-х годов уровень автомобилизации крупнейших городов России составил 250 автомобилей на 1000 жителей, а по России в целом - 
145 автомобилей на 1000 жителей). На начало 2012 года на каждую 1000 жителей страны приходится по 250 легковых автомобилей, что в три раза меньше, чем в США, и почти в два раза меньше, чем в среднем по Европе. При этом в крупнейших городах России наибольшим уровнем автомобилизации обладают: Владивосток 556 автомобилей на 1000 жителей, Сургут, Красноярск, Тюмень и Москва (360 автомобилей на 1000 жителей). Согласно данным ООН, страной с самым высоким уровнем автомобилизации являются США, где на 1000 населения приходится 765 автомобилей.

В этих условиях действующие ставки транспортного налога не отражают разную степень воздействия легковых, грузовых автомобилей и автобусов на дорожную сеть страны, а также на экологию. Это не соответствует реальной нагрузке, которую оказывают транспортные средства на дорожную сеть и отличается от практики европейских стран, где эта разница нагрузки выражается в значительной дифференциации ставок транспортного налога.

Кроме того, существует проблема разделения транспортных средств по категориям. От категории транспортного средства зависит ставка налога и соответственно его сумма. Из-за отсутствия в Налоговом кодексе РФ ссылки на документ, которым необходимо руководствоваться при отнесении транспорта к той или иной категории, между налоговыми органами, налогоплательщиками и судами постоянно возникают разногласия - все они ссылаются на совершенно разные документы, которые даже не являются нормативными.

Так, многие налогоплательщики относят автомобили УАЗ-3962, УАЗ-3303, УАЗ-3909 к легковым, опираясь на их технические паспорта. Но некоторые арбитражные суды автомобиль УАЗ-3962 относят к автобусам, руководствуясь Отраслевой нормалью автомобильной промышленности и письмами завода-изготовителя, а автомобили УАЗ-3303 и УАЗ-3909 - относятся к категории грузовых, поскольку об этом также свидетельствует заключение завода-изготовителя ${ }^{8}$.

В настоящее время транспортной стратегией определены проекты общегосударственного значения в области транспортной инфраструктуры, которые должны быть реализованы в период до 2020 года9 Объективной особенностью объектов подобного типа является их исключительно высокая фондоемкость, длительные сроки реализации и окупаемости этих проектов. Анализ ресурсного обеспечения мероприятий Стратегии показал, что текущий уровень финансирования транспорта, составляющий около 2,4\% от ВВП, явно недостаточен. Задача удвоения ВВП требует опережающего развития экономической инфраструктуры, в частности - в области транспорта. Расчеты свидетельствуют о необходимости доведения ежегодного финансирования транспортного комплекса до уровня порядка 4\% ВВП. Только на развитие автомобильной сети дорог общего пользования надо ежегодно направлять не менее 450 млрд. рублей. А ведь помимо дорожной отрасли, такие же потребности в увеличении финансирования испытывают железные дороги, морские пути и воздушный транспорт.

Опыт развитых стран доказывает, что инвестиции в транспортную инфраструктуру являются одним из наиболее

\footnotetext{
${ }^{8}$ Паневина E.B. определение категории транспортного средства в целях налогообложения/ E.В. Паневина// Налоговед. - 2009. - № 3. - с. 19-23.

${ }^{9}$ Распоряжение Правительства РФ от 17.11.2008 № 1662-р «О Концепции долгосрочного социально-экономического развития Российской Федерации на период до 2020 года»
} 


\section{Налоги и налогообложение - №1(103) • 2013}

эффективных инструментов ускорения экономического роста, развития новых рынков, формирования новых возможностей для повышения инвестиционной, деловой и социальной активности в обществе. Приоритетность инфраструктурной составляющей в обеспечении высоких темпов роста и проведении качественных структурных преобразований в экономике страны была особо отмечена в последнем Послании Президента к Федеральному собранию Российской Федерации ${ }^{10}$.

Основными проблемами автомобильных дорог остаются:

- высокая степень износа и неудовлетворительное техническое состояние большинства российских автодорог. Только на федеральной сети в серьезной реконструкции и модернизации нуждается не менее трети существующих дорог и не менее 15\% эксплуатируемых мостов и путепроводов. Около 58\% протяженности федеральных автомобильных дорог не соответствовали современным нормативным требованиям по транспортно - эксплуатационным показателям;

- низкая пропускная способность - сегодня около 8 тысяч километров автомобильных дорог работают в режиме перегрузки, а на отдельных участках вблизи крупных городов общей протяженностью около 1,5 тысяч километров наблюдаются систематические многочасовые заторы;

- низкая плотность и неоптимальная конфигурация дорожной сети, которая приводит к значительному перепробегу автотранспортных средств. В результате - себестоимость автомобильных перевозок сегодня в России в 1,5 раза выше, чем в развитых зарубежных странах;

\footnotetext{
${ }^{10}$ Основные направления налоговой политики Российской Федерации на 2011 год и на плановый период 2012 и 2013 годов
}

- $\quad$ рост аварийности и смертности на дорогах. В год число погибших достигает 35 тысяч человек. И хотя по статистическим данным недостатки дорог являются причиной только около $25 \%$ аварий, необходимы серьезные меры для существенного снижения этих немалых цифр;

- отсутствие подъездов с твердым покрытием к значительному количеству населенных пунктов. Сегодня около 50 тыс. населенных пунктов не имеют круглогодичной связи по дорогам с твердым покрытием.

При этом на фоне снижения финансирования, растет налоговая нагрузка отрасли.

- уже сегодня состояние автодорожной инфраструктуры становится одним из основных факторов, сдерживающих экономический рост в стране.

При сохранении существующих тенденций к 2015 году ${ }^{11}$ :

- свыше 75\% автомобильных дорог не будут соответствовать нормативным и транспортно-эксплуатационным требованиям, будет иметь место значительное разрушение дорожной сети;

- количество дорожно-транспортных происшествий возрастет на 40-45\%.

- возникнут хронические заторы на подходах к крупным городам, протяженность федеральных автодорог с превышением нормативной загрузки возрастет в 4 раза, что приведет к снижению средней скорости движения на дорогах страны не менее чем на $20 \%$.

В результате использования различных методов, в развитых странах за последние 40-50 лет было установлено, что в качестве единственного действенного регулятора пропускной способности до-

\footnotetext{
${ }^{11}$ О налоговой политике в России до 2013 года // Финансы. - 2010. - №3. - c. 19-22
} 
рожной являются налоги на транспорт и право им обладания:

- налоги на доступ к сети как таковой, то есть на владение (приобретение, пользование) транспортными средствами (B2),

- налогов в виде «дорожных пошлин для проезжающих» отдельные участки сети и искусственные сооружения на ней (B1),

- налоги, пропорциональные фактическому пользованию сетью дорог, то есть фискальная составляющая в цене моторных топлив, масел и прочих эксплуатационных материалов (B3).

Цивилизованно-рыночный механизм платы за дороги ассоциируется с финансированием дорожного хозяйства за счет целевых налогов, направляемых в специальные дорожные фонды. Экономический рубеж перехода определяется уровнем автомобилизации, при котором общая масса целевых дорожных налогов, взимаемая с владельцев транспортных средств, становится достаточной для финансирования дорожного хозяйства.Сравнительный анализ зарубежных стран показывает, что рубеж достаточности находится на уровне около 180 автомобилей на 1000 жителей. Но во всех этих странах задачи дорожного строительства были решены задолго до наступления автомобильного бума.
В России в последние годы темпы дорожного строительства отстают от темпов роста экономики страны и темпов прироста автопарка. Темпы прироста автопарка составляют 7-10\% в год. Общий прирост протяженности автодорог в РФ составил менее $1 \%$. За счет федерального бюджета до 2020 года в России планируется построить 18 тысяч километров автомобильных дорог. А объем дорожных фондов к этому времени может составить более восьми триллионов рублей. Но данных темпов явно недостаточно ${ }^{12}$. Для повышения темпов дорожного строительства необходимо снова сделать транспортный налог целевым. Все суммы, собираемые по данному налогу должны строго расходоваться на дорожное строительство и развитие транспортной инфраструктуры. Для достижения данных целей нами предлагается изменить порядок расчета налоговой базы по наземным транспортным средствам.

В таблицах 7 и 8 мы предложили несколько вариантов расчета суммы транспортного налога исходя из несколько иных принципов формирования налоговой базы. Данные рекомендации учитывают передовой мировой опыт налогообложения транспортных средств. Конечный вариант будет всецело зависеть от целей, которые ставит перед собой правительство РФ.

Таблица 7 - Исходные данные для сравнения налогообложения транспортным налогом автомобиля

\begin{tabular}{|c|c|c|c|c|}
\hline $\begin{array}{c}\text { С мощности } \\
\text { двигателя в л.с. }\end{array}$ & 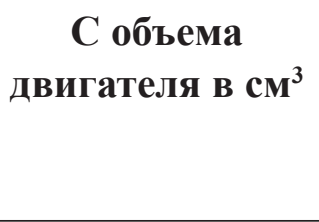 & $\begin{array}{c}\text { С массы автомо- } \\
\text { биля в тоннах }\end{array}$ & $\begin{array}{c}\text { От объёма } \\
\text { выброса за- } \\
\text { грязняющих ве- } \\
\text { ществ г/км }\end{array}$ & $\begin{array}{c}\text { От стоимости } \\
\text { автомобиля } \\
\text { в тыс. руб. }\end{array}$ \\
\hline 1 & 2 & 3 & 4 & 5 \\
\hline до 100 л.с. & до 1600 & до 1,5 & до 100 & до 300 \\
\hline
\end{tabular}

\footnotetext{
12 Указ Президента РФ от 12.05.2009 № 537 «О Стратегии национальной безопасности Российской Федерации до 2020 года»
} 
Налоги и налогообложение - №1(103) • 2013

\begin{tabular}{|c|c|c|c|c|}
\hline $\begin{array}{c}\text { от } 100 \text { л.с. } \\
\text { до } 150 \text { л.с. }\end{array}$ & от 1601 до 2000 & от 1,5 до 2,2 & от 101 до 150 & от 301 до 1000 \\
\hline $\begin{array}{c}\text { от } 150 \text { л.с. } \\
\text { до } 200 \text { л.с. }\end{array}$ & от 2001 до 3000 & от 2,2 до 3,0 & от 151 до 200 & от 1001 до 2000 \\
\hline $\begin{array}{c}\text { от } 200 \text { л.с. } \\
\text { до } 250 \text { л.с. }\end{array}$ & от 3001 до 4500 & Свыше 3,0 & свыше 201 & от 2001 до 5000 \\
\hline свыше 250 л.с. & свыше 4501 & - & - & свыше 5001 \\
\hline
\end{tabular}

Так как основной проблемой для наземного транспорта является низкая пропускная способность дорожной сети и её неразвитость то целесообразнее было бы выбрать в качестве налоговой базы объём двигателя. Подробный расчет суммы транспортного налога в зависимости от размера налоговой базы представлен в таблице 8 .
Из расчёта видно, что даже при небольших налоговых ставках сумма налога, при базе в виде объема двигателя, получается выше, чем при иных её вариантах. При этом учитывается и то факт, что более дорогие автомобили имеют и более объёмные и мощные моторы. Взимание же налога в процентах от его стоимости, в наших условиях является

Таблица 8 - Сравнение различных вариантов расчета транспортного налога для автомобиля

\begin{tabular}{|c|c|c|c|c|c|c|c|c|c|}
\hline \multicolumn{2}{|c|}{$\begin{array}{c}\text { С мощности } \\
\text { двигателя } \\
\text { в л.с. }\end{array}$} & \multicolumn{2}{|c|}{$\begin{array}{c}\text { С объема } \\
\text { двигателя в см³ }\end{array}$} & \multicolumn{2}{|c|}{$\begin{array}{c}\text { С массы } \\
\text { автомобиля } \\
\text { в тоннах }\end{array}$} & \multicolumn{2}{|c|}{$\begin{array}{c}\text { От объёма вы- } \\
\text { броса загрязняю- } \\
\text { щих веществ }\end{array}$} & \multicolumn{2}{|c|}{$\begin{array}{c}\text { От стоимости } \\
\text { автомобиля } \\
\text { в тыс. руб. }\end{array}$} \\
\hline $\begin{array}{c}\text { Ставка } \\
\text { в рублях } \\
\text { за } 1 \text { л.с. }\end{array}$ & $\begin{array}{l}\text { Сумма в } \\
\text { рублях }\end{array}$ & $\begin{array}{c}\text { Ставка } \\
\text { в рублях } \\
\text { за } 1 \mathrm{~cm}^{3}\end{array}$ & $\begin{array}{l}\text { Сумма } \\
\text { в рублях }\end{array}$ & $\begin{array}{c}\text { Ставка } \\
\text { в рублях } \\
\text { за } 1 \text { кг }\end{array}$ & $\begin{array}{l}\text { Сумма } \\
\text { в рублях }\end{array}$ & $\begin{array}{c}\text { Ставка } \\
\text { в рублях } \\
\text { за } 1 \text { г/ } \\
\text { км }\end{array}$ & $\begin{array}{c}\text { Сумма } \\
\text { в рублях }\end{array}$ & $\begin{array}{c}\text { Ставка } \\
\text { в \% }\end{array}$ & $\begin{array}{l}\text { Сумма } \\
\text { в рублях }\end{array}$ \\
\hline 1 & 2 & 3 & 4 & 5 & 6 & 7 & 8 & 9 & 10 \\
\hline 20 & 2000 & 2 & 3200 & 2 & 3000 & 20 & 2000 & 0,5 & 1500 \\
\hline 30 & $\begin{array}{c}3030- \\
4500\end{array}$ & 3 & $\begin{array}{c}4803- \\
6000\end{array}$ & 4 & $\begin{array}{c}6000- \\
8800\end{array}$ & 30 & $\begin{array}{l}3030- \\
4500\end{array}$ & 1 & $\begin{array}{l}3000- \\
10000\end{array}$ \\
\hline 50 & $\begin{array}{l}7550- \\
10000\end{array}$ & 4 & $\begin{array}{l}8001- \\
12000\end{array}$ & 7 & $\begin{array}{l}15400- \\
21000\end{array}$ & 40 & $\begin{array}{c}6040- \\
8000\end{array}$ & 1,5 & $\begin{array}{l}15000- \\
30000\end{array}$ \\
\hline 75 & $\begin{array}{c}15075- \\
18750\end{array}$ & 5 & $\begin{array}{l}15005- \\
22500\end{array}$ & 10 & 30000 & 50 & 10050 & 2 & $\begin{array}{l}40000- \\
100000\end{array}$ \\
\hline 150 & 37650 & 10 & 45010 & - & - & - & - & 3 & 150000 \\
\hline
\end{tabular}


контрпродуктивным, так как тут надо будет учитывать износ автомобиля и соответственно падение его стоимости. Практика показывает, что уже после первого года эксплуатации новый автомобиль теряет не менее $30 \%$ своей первоначальной стоимости. Кроме того, это приведет к тому, что увеличиться число старых машин на дорогах, что еще более повысит аварийность.

Таким образом, это позволит переломить негативные тенденции в развитии дорожной отрасли. И возможно будет способствовать переходу к точному, а с учетом отставания финансирования дорожного хозяйства, одновременно эффективному управлению и расходованию бюджетных средств на основе среднесрочного планирования и бюджетирования, ориентированного на результат.

Следует так же отметить, что дальнейшие пути совершенствования должны заключаться не только в изменении законодательной базы (порядка расчета налоговой базы, ставок налога, объектов, сроков уплаты и представляемой документации) в этой области на основе выявления наиболее значимых ошибок, но также в радикальном повсеместном изменении отношения налоговых органов к своей работе, что является одним из приоритетов налоговой политики. К сожалению, транспортный налог в настоящее время не является целевым из-за чего финансирование строительства дорожной сети остаётся на низком уровне и препятствует экономическому росту страны. Так как при должном уровне развития транспортной сети и инфраструктуры темп роста экономика страны будет на 2-3\% выше существующего.

\section{Библиография:}

1. Берестовой А. А. Правовое регулирование транспортного налога : дис. ... канд. юрид. наук : 12.00.14 / А. А. Берестовой; Ростов-на-Дону, Рост. гос. эконом. ун-т ; науч. рук. А. Н. Позднышов. - Ростов-наДону, 2012 . - 169c.

2. Данные по формам статистической налоговой отчетности// www.nalog.ru: сервер Федеральной Налоговой Службы России. URL: http://www.nalog.ru/ nal_statistik/forms_stat (дата обращения 10.01. 2013).

3. Налоговый кодекс Российской Федерации часть первая от 31 ию-ля 1998 г. № 146Ф3 и часть вторая от 5 августа 2000 г. № 117-Ф3 (с изм. и доп. от 09.09.2012г.)// Справочно-правовая система «Гарант»: [Электр.ресурс]/НПП «Гарант-Сервис». - Послед. обновление 10.01.2013.

4. О налоговой политике в России до 2013 года // Финансы. - 2010. - №3. - с. 19-22

5. Основные направления налоговой политики Российской Федера-ции на 2011 год и на плановый период 2012 и 2013 годов [Электронный ре-сурс] — Режим доступа <URL: www.pnalog.ru/material/vychetnds-pri-perechislenii-avansa

6. Паневина Е.В. определение категории транспортного средства в целях налогообложения/ Е.В. Паневина//Налоговед. - 2009. - № 3. - c. 19-23.

7. Петухова, Н.Е. История налогообложения в России IX-XX вв./Н.Е. Петухова - М.: Вузовский учебник, 2011. - 416 с.

8. Распоряжение Правительства РФ от 17.11.2008 № 1662-р «О Концепции долгосрочного социально-экономического развития Российской Федерации на период до 2020 года» (вместе с “Концепцией долгосрочного социально-экономического развития Российской Федерации на период до 2020 года")// Справочно-правовая система «Консультант Плюс»: [Электр. ресурс] /СПС «Косультатн Плюс». Послед. обновление 08.10.2012. 


\section{Налоги и налогообложение - №1(103) • 2013}

9. Российский статистический ежегодник, 2011 [Электронный ре-сурс] / Федеральная служба государственной статистики (Росстат). - Элек-трон. текстовые дан. - М. : Статистика России, 2011 . - электрон, опт. диск (CD-ROM) . - Загл. с этикетки диска.

10. Собрание действующего законодательства СССР: Законодатель-ство о финансах и кредите. Т. 14: Разд. 5: Кн. 1 / Гл. ред.: Георгадзе М.П., Колибаб К.Е., Самощенко И.С., Смиртюков М.С., Теребилов В.И. (Гл. ред.) - М.: Известия, 1974. -592 c.

11. Указ Президента РФ от 12.05.2009 № 537 «О Стратегии нацио-нальной безопасности Российской Федерации до 2020 года» // Справочно-правовая система «Консультант Плюс»: [Электр.ресурс] /СПС
«Косультатн Плюс». - Послед. обновление 08.10.2012.

\section{References (transliteration):}

1. Berestovoy A. A. Pravovoe regulirovanie transportnogo naloga : dis. ... kand. yurid. nauk : 12.00 .14 / A. A. Berestovoy; Rostovna-Donu, Rost. gos. ekonom. un-t ; nauch. ruk. A. N. Pozdnyshov. - Rostov-na-Donu, 2012.-169s.

2. Panevina E.V. opredelenie kategorii transportnogo sredstva $\mathrm{v}$ tselyakh nalogooblozheniya/ E.V. Panevina//Nalogoved. 2009. - № 3. - s. 19-23.

3. Petukhova, N.E. Istoriya nalogooblozheniya v Rossii IX-XX vv./N.E. Petukhova - M.: Vuzovskiy uchebnik, 2011. - 416 s. 